\title{
Pathogenic and molecular characterisation of Pythium spp. inducing root rot symptoms in other crops intercropped with beans in Southwestern Uganda
}

\author{
Virginia Gichuru a, b, Robin Buruchara ${ }^{b}$ and Patrick Okori a \\ a Department of Crop Science, Makerere University, P.O.Box 7062, Kampala, Uganda \\ b International Centre for Tropical Agriculture (CIAT), Kawanda, Kampala, P.O.Box 6247, Kampala, Uganda \\ Corresponding author:virginia.gichuru@gmail.com
}

Original submitted in on 22 ${ }^{\text {nd }}$ April 2016. Published online at www.m.elewa.org on 31st August 2016

http://dx.doi.org/10.4314/jab.v104i1.8

\begin{abstract}
Objective: In Southwestern Uganda, bean root rot epidemics associated with Pythium species are frequent despite the use of various management methods. This study set out to determine whether other crops in bean cropping systems of Southwestern Uganda are affected by Pythium root rots and to characterise the Pythium species using Internal transcribed sequence (ITS) DNA primers.

Methodology and Results: Root rots were found to occur on maize, sorghum, peas and potato sampled from farmer's fields where they were found to be intercropped with beans affected by root rot. Pythium species were isolated using Corn meal agar (CMA).DNA was subsequently extracted and polymerase chain reaction (PCR) analysis carried out using ITS DNA region primers and then the PCR products were sequenced. Twenty-one Pythium species were isolated. Cross pathogenicity tests were done in a screen house using bean pathogenic Pythium species and Pythium, species derived from other crops intercropped with beans. The Pythium species were moderately to non-pathogenic in maize and millet while those in sorghum and peas were highly pathogenic.

Conclusion and application of results: This study found that other crops intercropped with beans in Southwestern Uganda were affected by Pythium root rots. Peas and sorghum were highly susceptible to the pathogenic Pythium species and could therefore be contributing to the continuous bean root rot epiphytotics in the region. On the other hand, maize and millet were non pathogenic to the Pythium species. This knowledge could be used to advice farmers not to include sorghum and peas when intercropping with beans, as they seem to be contributing to the Pythium inoculum load. They could alternatively use maize and millet, as they are not susceptible to the pathogenic Pythium species.
\end{abstract}

Key words: Pythium, root rots, Southwestern Uganda, ITS DNA, pathogenic

\section{INTRODUCTION}

The common bean (Phaseolus vulgaris L.) is the second most important source of human dietary protein and the third most important source of calories of all agricultural commodities produced in Eastern and Southern Africa (Sarikamis et al., 2009).
Eastern Africa has the highest bean production in sub-Saharan Africa at 75,369 metric tonnes per annum $(F A O, 2004)$.In Uganda, beans are grown throughout the country but especially in the cool highlands of Southwestern Uganda 


\section{Gichuru et al. J. Appl. Biosci. 2016 Pathogenic and molecular characterisation of Pythium spp. inducing}

root rot symptoms in other crops intercropped with beans in Southwestern Uganda

(Mukalazi,2004). These areas lie at an altitude of 800-2,300 metres above sea level. In most parts of Africa, common beans are grown as an intercrop with other food crops, especially maize. Such cropping methods with little or no added inputs such as fertilisers or pesticides, do not allow beans to realise their maximum yield potential (Nderitu et al.1997).Consequently under such production systems, the biotic and abiotic constraints seriously reduce yield. One of the biotic constraints affecting bean production is root rots. The occurrence and severity of root rot disease is associated with high intensity of bean growing attributed to lack of crop rotation. Root rots are caused by one or more soil borne pathogens either alone or as a complex of two or more pathogens depending on environmental conditions (Rusuku et al., 1997). Bean root rots are characterised by above ground symptoms such as poor seedling establishment, uneven growth, chlorosis and premature defoliation of severely infected plants (Abawi and Ludwig,2005; CIAT 2005).A study done on farmers' fields in Southwestern Uganda, found differing root rot lesions on maize, sorghum, peas and beans (CIAT, 2005). In Southwestern Uganda, bean root rot epidemics associated with Pythium spp. are frequent (Rusku et al., 1997).Various management options such as use of resistant cultivars and crop rotation have been used to control root rots of beans (Abawi and Pastor-Corrales, 1990). In Africa, the integration of organic amendments, raised beds and resistant

\section{MATERIALS AND METHODS}

\section{Sample collection and purification of Pythium}

spp.: Samples of crops intercropped with beans with or without typical symptoms of root rot were collected from bean root rot fields in Southwestern Uganda (Fig 1). Samples were picked from a pre-determined position using a grid distance of 5 to $10 \mathrm{~km}$. In each of the sampled fields, crops were selected following a "W" pattern. Ten plants were sampled for tall crop species and twenty for short crop species. The sampling procedure was repeated in three different years/seasons. Root rot symptoms on crops were observed and noted during sampling. These symptoms included rotten stems in sorghum and reduced root system in pea and sweetpotato (Table 2). Once the crop samples were collected, the isolation procedure described by White varieties has been shown to be advantageous over single components in controlling the severity of root rots and yield (Buruchara and Scheidegger, 1993; CIAT, 1993). Studies on root rots have indicated that continuous cropping of beans, which is a common practice in East Africa, exacerbates the root rot problem (Rusuku et al., 1997).In most cases due to population and land pressure, beans are often intercropped with other crops (Ocitti p'Obwoya, 1996). The objectives of this study are firstly to determine whether root rots occur in other crops in a bean based system in Southwestern Uganda. Secondly, to characterise using ITS DNA sequences those Pythium species responsible for Pythium root rots on those crops intercropped with beans. This is to ascertain if new Pythium species are implicated in bean root rot epidemics in the region. It is known that the bean-Pythium pathosystem has been subjected to selection pressure which could result in parasite population modification (CIAT, 1992). The aim of the study would also be to understand if other crop species in the system are influencing root rot epidemics. Since Pythium variability on beans is known, Koch's postulate will be used to investigate the cross pathogenicity properties of Pythium species on other crops in the bean-based system of Southwestern Uganda. The aim would be to generate information, which is critical for formulating integrated management options for bean root rot epidemics.

(1988) was used to isolate the Pythium species from root pieces of the crops. A selective medium was prepared by mixing corn meal agar, CMA $(20 \mathrm{~g})$ and deionised water $(1000 \mathrm{ml})$ before autoclaving at $15 \mathrm{psi}$ for 20 minutes. The antibiotic preparation (rifamycin $(45 \mu \mathrm{g} / \mathrm{ml})$ and pimaricin $(100 \mu \mathrm{g} / \mathrm{ml})$ were added on cooling the media to $40^{\circ} \mathrm{C}$. Isolations from crop samples were done by first washing soil from plant tissues in a jet-stream of tap water, rinsing twice in sterile distilled water, blotting dry on new paper towel, and placing infected root pieces (approximately $0.5-2 \mathrm{~cm}$ long) cut from expanding lesions on the prepared selective medium (CMA). These petridishes with CMA were incubated at room temperature $\left(20-25^{\circ} \mathrm{C}\right)$ for $2-5$ days. The Pythium mycelia developing from plant tissues were transferred onto potato dextrose agar (PDA) slants. 


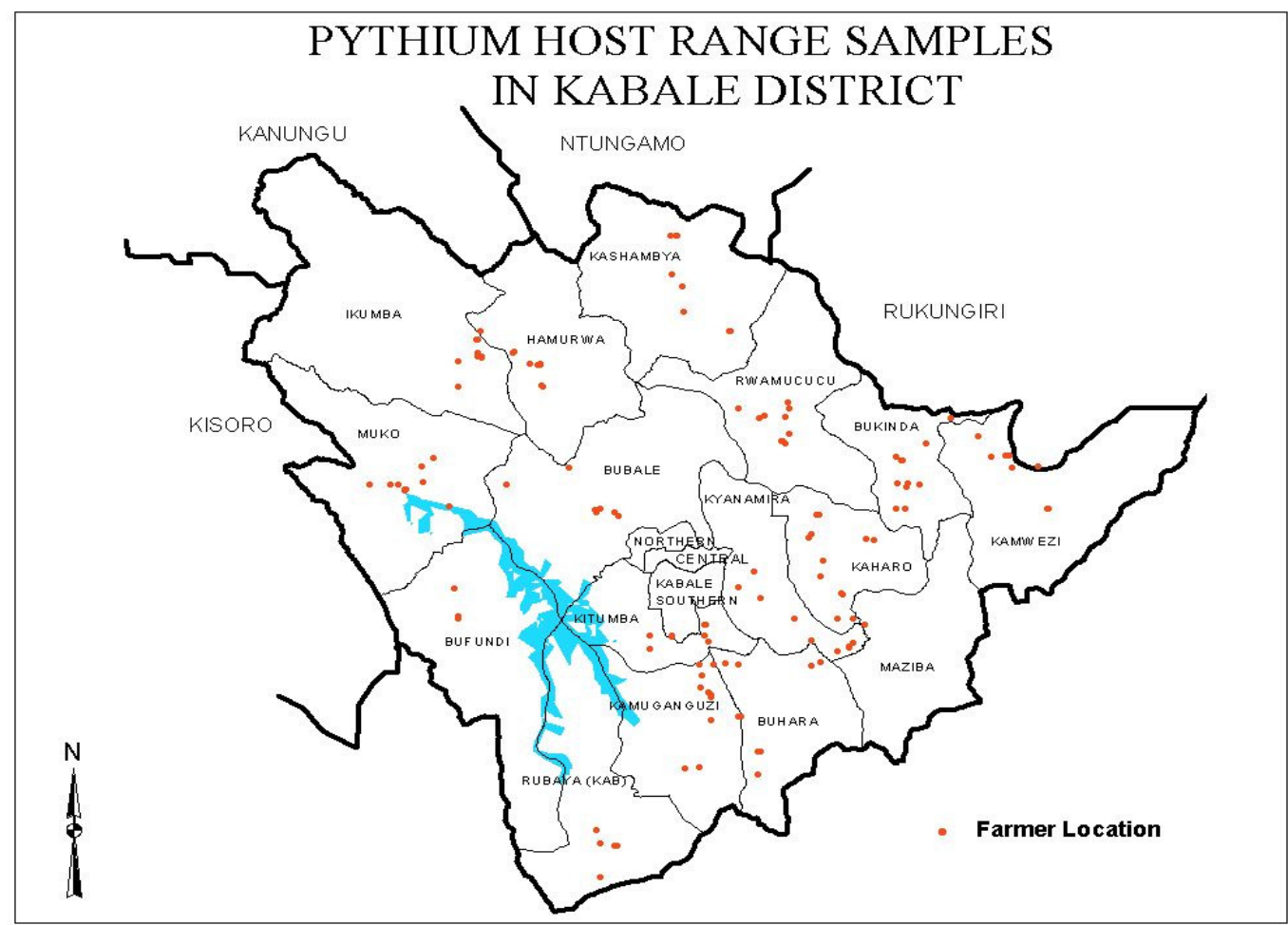

Figure1: A map of southwestern Uganda where samples were obtained for the study.

DNA extraction: After two to three days, a plug of pure culture from Potato Dextrose Agar (PDA) was cut from the growing margin of cultures and placed in sterilised $20 \%$ V8 juice broth containing $2.5 \mathrm{~g}$ of $\mathrm{CaCO}_{3}$. After four days of incubation in darkness at room temperature, mycelia was harvested using sterilised forceps, filtered through a layer of $85-\mathrm{mm}$ filter paper and blot dried of excess V8 juice with paper towels. DNA was extracted from the harvested mycelia according to the procedure described by Mahuku (2004). Mycelia were ground to a fine paste in a mortar containing TES extraction buffer (0.2 M Tris- $\mathrm{HCl}(\mathrm{pH} 8), 10 \mathrm{mM}$ EDTA (pH 8), $0.5 \mathrm{M} \mathrm{NaCl}, 1$ $\%$ SDS) and sterilized acid-washed sea sand. Additional TES buffer containing proteinase $\mathrm{K}$ was added and the mixture incubated at $65^{\circ} \mathrm{C}$ for 30 minutes. DNA was precipitated using ice-cold isopropanol and the pellet was washed twice with $70 \%$ ethanol, dried and dissolved in TE buffer (10mM Tris-HCl (pH8), 1mM EDTA). Polymerase Chain Reaction: PCR analysis was done using oomycete ITS (Internal Transcribed Sequence) region primers to differentiate Pythium from other closely related fungi (White et al.1990). The PCR reaction was performed in $50 \mu$ f final reaction volume containing $5 \mu$ l of $1.25 \mathrm{mM}$ dNTP, $0.2 \mu \mathrm{l}$ of each primer $(20 \mu \mathrm{M})(18 \mathrm{~S}$ ( 5'TCC GTA GGT GGT GAA CCT GCG G-3') and $28 \mathrm{~S}$ (\%'TCC TCC GCT TAT TGA TAT GC-3') 20 ng of DNA and
$0.2 \mu \mathrm{l}$ Taq DNA polymerase (5 U/ $\mu$ l) (CIAT Virology Laboratory, Cali, Colombia). Amplification was performed in a Primus 96 plus Thermal Cycler (MWG-Biotech, Germany),programmed for 35 cycles of denaturation at $94{ }^{\circ} \mathrm{C}$ for $1 \mathrm{~min}$, annealing at $68^{\circ} \mathrm{C}$ for $2 \mathrm{~min}$, and extension at $72^{\circ} \mathrm{C}$ for $1 \mathrm{~min}$. At the end of the amplification reaction, a final extension step was achieved at $72^{\circ} \mathrm{C}$ for 7 minutes. The products were run on $2 \%$ agarose gels containing $5 \mathrm{mg} / \mathrm{ml}$ of ethidium bromide in a TBE (1 time concentrated) as the running solution. The electrophoretic migration was carried out during $2 \mathrm{~h}$ under a $100 \mathrm{~V}$ (voltage). The amplified products were visualised and photographed under UV light. To estimate the size of the PCR products, a 100bp (base pair) molecular ladder was used. The negative controls were PCR amplifications containing no DNA template. Sequencing of amplified DNA and Pythium identification: All the PCR products having a size of 800 bp were submitted to sequencing procedure. Residual primers and dNTPs in the PCR products were removed using QIAquick ${ }^{\mathrm{TM}}$ PCR purification spin columns, following the manufacturer's protocol (QIAGEN,Crawley,UK). Direct sequencing of the PCR amplified products was carried out using ITS 2 primer (White et al.1990).Sequencing reaction of the double stranded DNA templates were carried out using the $A B I$ 
Prism ${ }^{\mathrm{TM}}$ Dye terminator cycle sequencing ready reaction kit (Applied Biosystems,CA-USA).The products were purified by ethanol precipitation following the manufacturer's protocol and nucleotide sequences were determined by the $\mathrm{ABI} 377$ automated sequencing technology (Applied Biosystems,CA-USA). Sequences from ITS 1 region of the ribosomal gene were edited using the BioEdit programme (DNASTAR Inc., Madison,Wis, USA). The ITS 1 sequences were aligned to sequences deposited at the National Centre for Biotechnology Information (NCBI Gene Ban)using blastN (http://www.ncbi.nih.gov/BLAST.) Multiple alignments of the sequenced ITS product was performed for comparison. Pythium sequences obtained were aligned with Clustal X (Thompson et al., 1994).Consequently; sequences were saved in Phylip formant and used for phylogenetic analysis. A neighbour-joining tree was drawn using Clustal $X$ and the boot strapping done to generate trees using 1000 replications. The Tree View software was used to view trees.

Pathogenicity analyses of the Pythium spp.: Cross pathogenicity tests of some crop species with bean pathogenic Pythium species as well as Pythium species pathogenic to other crops found in a bean-based system were done. These experiments were performed at the National Agricultural Research Laboratories, Kawanda. This site is located at $0025^{\prime} 05^{\prime \prime} \mathrm{N}$ and $32^{\circ} 31^{\prime} 54^{\prime \prime} \mathrm{E}$ at $1190 \mathrm{~m}$ above sea level (masl),average rainfall is 1224 $\mathrm{mm}$ per annum and average daily temperatures are $15.3^{\circ} \mathrm{C}$ (minimum) and $27.3^{\circ} \mathrm{C}$ (maximum). Four Pythium species previously found to be pathogenic on beans were used (Mukalazi, 2004).These isolates were MS 61 (P.ultimum var. ultimum), KAK 5B (P.macrosporum), VIHA 2A (P.chamaehyphon) and JM 29A (P.pachycaule). In addition, seven Pythium species obtained from crops intercropped with beans during sample collection in this

\section{RESULTS}

The sampling of crops for Pythium root rot was done in Kabale district (Fig 1).In this study, the main crops found to be intercropped with beans are shown in Table 1. In most cases, beans were found to be the major crop grown followed by potato, maize, sorghum and sweet potato. Various intercropping combinations were found. For instance, sweet potato was intercropped with study were used. These include P.macrosporum, P.oligandrum, P.spinosum (isolated from sorghum), P.glomeratum (isolated from potato), P.arrhenomanes (isolated from maize), P.heterothallicum (isolated from sweet potato) and P.ultimum. Inoculum of the various Pythium species above was multiplied by plating mycelia on autoclaved millet grains $(100 \mathrm{~g})$ mixed with $200 \mathrm{ml}$ of water in $500 \mathrm{ml}$ bottles. After two weeks of incubation under darkness at $25^{\circ} \mathrm{C}$, presterilised soil was mixed with the infested millet at a ratio of $1: 10 \mathrm{v} / \mathrm{v}$ in wooden trays of $42 \times 72 \mathrm{~cm}$. Each tray contained 10 plants of maize (Zea mays), sorghum (Sorghum bicolor), peas (Pisum satium), CAL 96(susceptible bean variety) and RWR 719 (resistant bean variety). The trays were set up in a Randomised Complete Block Design (RCBD) with three replications for each Pythium species. After germination, the seedlings were watered every day to provide a favourable environment for the pathogen establishment and development. Severity of root rots on seedlings was then estimated based on CIAT scale of 1-9 (Abawi and Pastor Corrales, 1990) where $1=$ no root symptoms, $3=a$ maximum of $10 \%$ of the hypocotyls and root tissue have lesions; $5=$ approximately $25 \%$ of the hypocotyls and root tissues have lesions and the root system suffers a considerable decay; $9=75 \%$ or more of the hypocotyls and root tissues have lesions and the root system suffers advanced stages of decay and considerable reduction. Pythium isolates which give a mean disease score of 1-2 were considered non-pathogenic; those, which gave a score of $3-5$, were considered mildly pathogenic and those that gave a score of 6-9 were highly pathogenic and virulent. Since the crops' roots varied in size, for disease scoring, five plants of maize, peas and beans (CAL 96 and RWR 719) were used, ten plants were used for sorghum and millet. This was to minimise between host variations and enhance estimation of the error level.

potatoes. Potatoes, maize and sorghum were grown in association with two other crops. Every farm had 1 to 6 different crop species intercropped with beans. During sample collection in farmers' fields, various crops were found to have symptoms characteristic of Pythium root rot (Table 2). 


\section{Gichuru et al. J. Appl. Biosci. 2016 Pathogenic and molecular characterisation of Pythium spp. inducing root rot symptoms in other crops intercropped with beans in Southwestern Uganda}

Table 1: Frequencies of the major crops grown in Kabale district in 2004, 2005 and 2006 cropping seasons.

\begin{tabular}{l|c|c|c}
\hline \multirow{2}{*}{ Crops } & \multicolumn{3}{|c}{ No. of farms where crops were growing (\%) } \\
\cline { 2 - 4 } & $\mathbf{2 0 0 4}$ & $\mathbf{2 0 0 5}$ & $\mathbf{2 0 0 6}$ \\
\hline Beans & 87.1 & 89.4 & 21.9 \\
Maize & 25.9 & 23.0 & 9.5 \\
Sorghum & 16.4 & 29.2 & 17.5 \\
Peas & 23.3 & 14.2 & 6.6 \\
Potato & 63.8 & 66.4 & 14.6 \\
Sweet potato & 14.7 & 10.6 & 9.5 \\
\hline
\end{tabular}

Table 2: Disease symptoms found on other crops intercropped with beans

\begin{tabular}{l|l}
\hline & Symptoms \\
\hline Beans & Root rot, Yellowing of leaves \\
\hline Maize & Yellow and red spots on leaves, Stem rotting \\
\hline Sorghum & $\begin{array}{l}\text { Rotten stem, Red lesions on stem, Leaves with black spots } \\
\text { Rotting roots,Stunting,Black purple leaves, Black roots, Drying of leaves }\end{array}$ \\
\hline Peas & Reduced root system, Root rot, Wilted leaves, Drying of roots, Yellowing stem \\
\hline Potato & $\begin{array}{l}\text { Wilted leaves, Rotten stems, Rotten roots, Black spots on leaves, Tubers rotting, } \\
\text { Yellowing of leaves }\end{array}$ \\
\hline Sweet potato & Reduced root system \\
\hline
\end{tabular}

Using ribosomal DNA sequences of the ITS region, 21 Pythium species were found to be associated with root rot in other crops commonly intercropped with beans. Five of these Pythium species i.e. P.spinosum, P.oligandrum, P.parvum, P.arrhenomanes and P.conidiophorum had been found associated with bean root rot (Mukalazi,
2004).Fifteen of the species sequences in this study were new and were identified for the first time in Southwestern Uganda during this study. In addition, P. ultimum was the most abundant Pythium species found in this study (39\%) (Table 3). 
Gichuru et al. J. Appl. Biosci. $2016 \quad$ Pathogenic and molecular characterisation of Pythium spp. inducing root rot symptoms in other crops intercropped with beans in Southwestern Uganda

\begin{tabular}{|c|c|c|c|c|c|c|c|c|c|c|c|c|c|c|}
\hline \multirow[b]{2}{*}{ Pythium spp. } & \multicolumn{14}{|c|}{ Crops sampled } \\
\hline & Potato & Sorghum & Maize & Bean & $\begin{array}{l}\text { Sweet } \\
\text { potato }\end{array}$ & Cabbage & Peas & Tomatoes & Millet & Wheat & Bananas & Weed & Yam & Total \\
\hline P. ultimum & 15 & 15 & 11 & 2 & 1 & 5 & 2 & - & - & 2 & 1 & - & 1 & 55 \\
\hline P. acanthicum & 5 & 3 & - & 1 & - & - & - & - & - & - & - & 1 & - & 10 \\
\hline P. spinosum & 3 & 4 & 1 & - & - & - & 1 & 1 & - & - & - & - & - & 10 \\
\hline P. torulosum & 2 & - & 2 & 1 & - & - & 1 & - & - & - & - & - & - & 6 \\
\hline P. folliculosum & 1 & 5 & 3 & 5 & - & - & 1 & - & - & - & - & - & - & 15 \\
\hline P. oligandrum & 1 & 4 & 2 & - & - & - & - & - & - & - & - & - & - & 7 \\
\hline P. parvum & - & 2 & - & - & - & 2 & - & - & 2 & - & - & - & - & 6 \\
\hline P.irregulare & 2 & - & - & - & - & - & - & 1 & - & - & - & - & - & 3 \\
\hline P. glomeratum & 2 & - & - & - & - & - & - & - & - & - & - & - & - & 2 \\
\hline P. heterothallicum & 1 & 1 & - & 1 & 2 & - & - & - & - & - & - & - & - & 5 \\
\hline P. rostratum & 1 & - & - & - & 1 & - & - & - & - & - & - & - & - & 2 \\
\hline P. arrhenomanes & - & 1 & - & - & - & - & - & - & - & - & - & - & - & 1 \\
\hline P. macrosporum & 1 & 1 & - & - & - & - & - & - & - & - & - & - & - & 2 \\
\hline P. mamillatum & 1 & - & - & - & - & - & - & - & - & - & - & - & - & 1 \\
\hline P. orthogonon & - & - & - & 1 & - & - & - & - & - & - & - & - & - & 1 \\
\hline P.arrhenomanes & - & - & 4 & - & - & - & - & - & 2 & - & - & - & - & 6 \\
\hline P. conodiophorum & - & - & - & 5 & - & - & - & - & - & - & - & - & - & 5 \\
\hline P. erinaceum & - & 1 & - & - & - & - & - & - & - & - & - & - & - & 1 \\
\hline P. periplocum & - & - & - & - & 1 & - & - & - & - & - & - & - & - & 1 \\
\hline P. vexans & - & 1 & - & - & - & - & - & - & - & - & - & - & - & 1 \\
\hline P.pachycaule & & 2 & & & & & & & & & & & - & 2 \\
\hline Total & 29 & 23 & 12 & 7 & 5 & 5 & 4 & 2 & 4 & 2 & 1 & 1 & 1 & 142 \\
\hline
\end{tabular}


Pathogenicity: The disease scores of root rot disease due to inoculation of various crops and bean plants in the screen house with bean pathogenic Pythium species is as indicated in Table 4. It was observed that maize and millet were moderately susceptible to bean pathogenic Pythium species (disease score of 3-5). However, sorghum and peas were highly susceptible to bean pathogenic Pythium species (disease score of 6-9). Root rot symptoms were observed in the trays inoculated with Pythium species and these symptoms were absent from the control trays without Pythium inoculum. Susceptible bean variety (CAL 96) displayed typical root rot symptoms, which included waterish stem and reduced root system (Plate 1). Sorghum had red-black lesions on the roots. Millet displayed the formation of prop roots while peas had brownish watery systems and root rots. Furthermore, there were above ground symptoms commonly associated with Pythium infection. Stunting was visible in sorghum and millet. Maize plants showed leaf chlorosis while the millet leaves dried up at the shoot tips. Sorghum leaves exhibited anthocyanescence in the inoculated trays.

Table 4: Mean disease scores of crop species after inoculation with bean pathogenic Pythium species

\begin{tabular}{|c|c|c|c|c|c|c|c|c|}
\hline & \multicolumn{8}{|c|}{ Crop Host Plants } \\
\hline Pythium species & $\begin{array}{l}\text { a Resistant } \\
\text { bean variety }\end{array}$ & $\begin{array}{l}{ }^{\mathrm{b}} \text { Susceptible } \\
\text { bean variety }\end{array}$ & Maize & Sorghum & Millet & Peas & $\begin{array}{c}\text { LSD } \\
(P \leq 0.05)^{d}\end{array}$ & CV (\%) ${ }^{\mathrm{e}}$ \\
\hline $\begin{array}{l}\text { Non inoculated } \\
\text { control c }\end{array}$ & 1.33 & 1.50 & 1.53 & 1.39 & 1.06 & 1.56 & 0.21 & 33.5 \\
\hline $\begin{array}{l}\text { P.ultimum var. } \\
\text { ultimum }\end{array}$ & 2.86 & 7.56 & 4.31 & 8.19 & 4.44 & 8.67 & 0.54 & 21.3 \\
\hline P.chamaehyphon & 3.14 & 7.89 & 5.26 & 8.08 & 5.42 & 8.28 & 0.56 & 19.9 \\
\hline P.macrosporum & 2.81 & 8.92 & 3.73 & 7.92 & 3.89 & 7.03 & 0.44 & 17.2 \\
\hline P.pachycaule & 3.03 & 8.44 & 4.75 & 8.61 & 4.78 & 8.33 & 0.49 & 17.7 \\
\hline $\operatorname{LSD}(P \leq 0.05)^{d}$ & 0.30 & 0.44 & 0.51 & 0.33 & 0.65 & 0.48 & & \\
\hline CV $(\%)^{\text {e }}$ & 24.2 & 13.9 & 27.9 & 10.3 & 35.7 & 15.2 & & \\
\hline
\end{tabular}

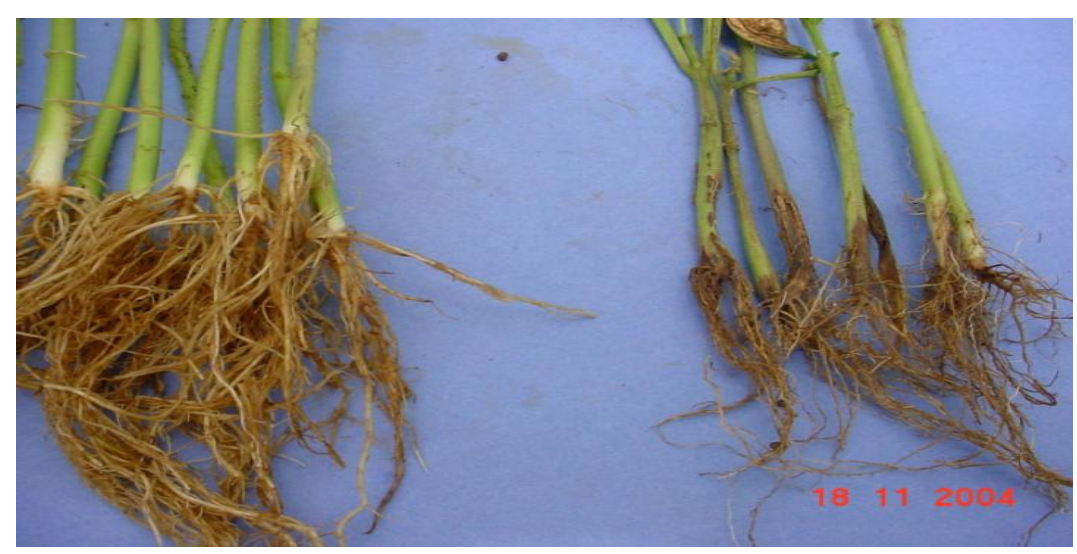

Plate 1: Root damage on the susceptible bean variety (CAL 96) right hand panel, and roots from non inoculated control (CAL 96). This root damage was used to assess severity of disease on a 1-9 scale (Abawi and Pastor-Corrales, 1990).

In addition, disease scores of root rot disease due to inoculation of various crops and bean plants with Pythium species isolated from crops intercropped with beans is indicated in Table 5. Peas were moderately pathogenic to P.glomeratum and P.ultimum (disease score 35).However, peas were highly pathogenic to
P. macrosporum, P.arrhenomanes and P.heterothallicum. Maize was moderately pathogenic to all Pythium isolates used. Millet was non-pathogenic. The susceptible bean variety (CAL 96) was non pathogenic to moderately pathogenic. 


\section{Gichuru et al. J. Appl. Biosci. 2016 Pathogenic and molecular characterisation of Pythium spp. inducing root rot symptoms in other crops intercropped with beans in Southwestern Uganda}

Table 5: Mean disease scores of crop species after inoculation with eight Pythium species from crops intercropped with beans

\begin{tabular}{|c|c|c|c|c|c|c|c|c|}
\hline & \multicolumn{8}{|c|}{ Crop Host Plants } \\
\hline Pythium species & $\begin{array}{l}\text { a Resistant } \\
\text { bean variety }\end{array}$ & $\begin{array}{l}{ }^{\mathrm{b}} \text { Susceptible } \\
\text { bean variety }\end{array}$ & Maize & Sorghum & Millet & Peas & $\begin{array}{c}\operatorname{LSD}(\mathrm{P} \leq \\
0.05)^{d}\end{array}$ & $\begin{array}{l}\text { CV } \\
(\%)^{e}\end{array}$ \\
\hline \multicolumn{9}{|l|}{ Pythium species } \\
\hline $\begin{array}{l}\text { Non inoculated } \\
\text { control c }\end{array}$ & 1.03 & 1.11 & 1.08 & 1.00 & 1.00 & 1.61 & 0.29 & 54.8 \\
\hline $\begin{array}{l}\text { Pythium } \\
\text { macrosporum }\end{array}$ & 3.28 & 3.19 & 4.31 & 6.36 & 1.06 & 6.17 & 1.00 & 52.4 \\
\hline $\begin{array}{l}\text { Pythium } \\
\text { arrhenomanes }\end{array}$ & 2.03 & 1.78 & 2.42 & 6.69 & 2.11 & 7.61 & 0.91 & 51.7 \\
\hline Pythium spinosum & 1.75 & 2.39 & 2.89 & 6.69 & 1.94 & 1.75 & 0.72 & 42.1 \\
\hline $\begin{array}{l}\text { Pythium } \\
\text { oligandrum }\end{array}$ & 3.47 & 0.94 & 3.31 & 6.72 & 1.44 & 3.94 & 1.01 & 69.4 \\
\hline $\begin{array}{l}\text { Pythium } \\
\text { heterothallicum }\end{array}$ & 2.17 & 4.53 & 3.44 & 7.06 & 1.25 & 7.69 & 0.93 & 45.9 \\
\hline P.glomeratum & 2.39 & 1.73 & 3.17 & 6.19 & 1.00 & 4.14 & 1.03 & 70.4 \\
\hline P.ultimum & 2.61 & 2.06 & 2.89 & 6.53 & 1.00 & 4.67 & 0.94 & 61.7 \\
\hline $\operatorname{LSD}(P \leq 0.05)^{d}$ & 0.95 & 0.47 & 0.42 & 0.41 & 0.61 & 0.72 & & \\
\hline $\operatorname{CV}(\%)^{\mathrm{e}}$ & 36.9 & 32.9 & 15.8 & 60.4 & 49.3 & 24.7 & & \\
\hline
\end{tabular}

\section{DISCUSSION}

In this study, a number of food crops were found to be intercropped with beans. In Africa, beans are largely intercropped (Ocitti p'Obwoya, 1996). For example in Rwanda, beans are seasonally rotated with sorghum or sweet potato (Rusuku et al., 1997). In Southwestern Uganda, beans are grown in an intensive agricultural system together with sorghum, maize, sweet potato, potatoes, bananas and garden peas (Ampaire, 2003).Intercropping sweet potato with beans is the most popular sweet potato based intercropping system in Uganda (Bashaasha et al., 1995). Moreover, intercropping beans is an important strategy for food security, improves labour use efficiency, enhances soil nutrients because of the different demands made by the mixture of crops (Ocitti p'Obwoya,1996). During this study, some of the crops intercropped with beans were found to also suffer from root rot disease. This correlates with other observations which indicate that most of the root rot pathogens of beans in fact attack many crop species (Agrios, 1997). There has been speculation that continuous intercropping of beans which is common in Southwestern Uganda and other areas in Africa has increased the root rot problem (Rusuku et al., 1997).Hence those crops with root rot symptoms and even those without but that had been intercropped with beans were isolated for Pythium causing root rot. This was done using ITS ribosomal DNA sequences. Sequence analysis of selected DNA fragments to determine species relationship using ITS DNA regions has been more accurate than any other technique (White et al., 1990).Analysing sequences especially the ITS region is a main focus of oomycetes (Levesque et al., 2004). Fifteen new Pythium species were identified from other crops during this study. Pythium pathogens cause root rot or seedling rot in a number of legumes and other crops (Harman, 2001; Harvey, 2004).In this study, P.ultimum was the most abundant Pythium species found. In other studies done in the same area, P.ultimum was also found to be the most abundant Pythium species where beans are grown (Mukalazi, 2004). Other Pythium species also found in this study on other crops were P.torulosum, P.folliculosum, P.acanthicum, P.spinosum and P.oligandrum. Previously, P.torulosum and P.folliculosum have been isolated from monocotyledons, bryophytes, green algae, soil and occasionally from dicotyledons and conifers (Levesque et al., 2004). In previous studies, P.acanthicum and P.oligandrum were found to be pathogens of mainly dicotyledons while also being mycoparasites (Chellemi et al., 2000). In studies done in Southwestern Uganda by Mukalazi (2004) found 
P.spinosum to cause severe root rot in beans. DNA sequence analysis showed diverse clades and subgroups that did not correspond to host or origin of occurrence of Pythium isolates. These results are similar to Cilliers et al. (2000) who compared ribosomal (rDNA) of Sclerotium rolfsii isolates and reported that there was no apparent clustering according to host/geographic origin. This study for the first time provides evidence to suggest that Pythium species are found on diverse crop species, which are usually grown with beans. This may play a role in affecting inoculum level and hence playing a role in the increase of bean root rot epidemics in Southwestern Uganda. In order to characterise these epidemics further, pathogenicity tests in the screen house were done using bean pathogenic Pythium species and Pythium species derived from other crops. Based on the data from the pathogenicity tests using bean pathogenic Pythium species, maize and millet were found to be moderately pathogenic while sorghum and peas were highly pathogenic. Further, using Pythium species derived from other crops, the reaction was similar with maize and millet being moderately pathogenic to being non-pathogenic while sorghum and peas were highly pathogenic. Symptoms observed because of inoculation with Pythium species included red-black roots in sorghum, prop roots in millet, peas had brownish watery stems as well as root rot. When vascular tissues are invaded by Pythium mycelium, they become discoloured (Agrios, 1997). If Pythium root rot occurs early in the life of the crop, it may

\section{ACKNOWLEDGEMENTS}

The authors would like to thank DFID-CSL for the funding of this project, CIAT-Kawanda and CIAT-Colombia for

\section{REFERENCES}

Abawi GS, Ludwig JW, 2005. Effect of three crop rotations with and without deep plowing on root rot severity and yield of beans. Annual Report Bean Improvement Cooperative 48:118-119.

Abawi GS, Pastor -Corrales MA, 1990. Root rots of beans in Latin America and Africa: diagnosis, research, methodologies and management strategies. Centro Internacional de Agricultura Tropical (CIAT), Cali, Colombia. 114 pp.

Agrios GN. 1997. Plant pathology. Fourth edition. Academic Press, San Diego, California.

Ampaire E, 2003. Farmers' Indigenous technical knowledge of bean disease management and communication systems in south western Uganda.M.Sc. thesis. Makerere University, Kampala. 127 pp. cause an infected root to produce multiple roots (Kucharek, 2000) as was observed in millet during this study. Pythium infection also results in wilting and older leaves of infected plants become yellow. This symptom is used as a positive diagnosis of Pythium root rot (Chase,1999).The symptoms associated with Pythium infection in peas include the roots being destroyed and pale yellow leaves (Malvic and Babadoost,2002). The pathogenicity studies indicate that cross pathogenicity is taking place whereby Pythium species derived from beans affect beans and other crops. In addition, Pythium species derived from other crops are pathogenic to beans and the host crops as well. The pathogenicity studies also indicate that Pythium species do not considerably affect the cereals (millet and maize) while they do affect sorghum and peas. This is an indication that sorghum and peas, which are part of the bean pathosystem in Southwestern Uganda, are contributing to continuous root rot epidemics since they too are affected. Maize and millet however would be good intercrops, as they are not affected. This study therefore provided the following information:

i) That other crops intercropped with beans in Southwestern Uganda are affected by root rots.

ii) These root rots can be attributed to Pythium species.

iii) Peas and sorghum are affected by Pythium species and could thus be contributing to continuous bean root rot epidemics in Southwestern Uganda.

providing the laboratory and technical facilities and assistance

Bashaasha B, Mwanga R, Ocitti p'Obwoya C , Ewell PT, 1995. Sweet potato in the farming and food systems of Uganda: A farm survey report, International Potato Centre (CIP), National Agricultural Research Organisation (NARO). 63 $\mathrm{pp}$.

Buruchara RA, Pastor-Corrales MA, Scheidegger U, 1999. Fusarium wilt disease caused by Fusarium oxysporum $f$. sp. Phaseoli on a common bean cultivar, G2333 in Rwanda and the Democratic Republic of Congo. Plant Disease 83:397.

Chase AR, 1999.Pythium root rot on ornamentals Western Connection Turf and Ornamentals 1:8

Chellemi DO, Mitchell DJ, Kannwischer-Mitchell ME, 2000. Pythium spp. associated with bell pepper 
production in Florida. Plant Disease 84:12711274.

CIAT, 1992. Pathology in Africa. CIAT Annual Report, 1992. Bean Programme, Cali, Colombia. 385 pp.

CIAT, 1993. Trends in CIAT commodities, 1993. Working Document No.128. Centro Internacional de Agricultura Tropical (CIAT), Cali, Colombia.

CIAT, 2005. Annual Report, 2005. Bean Improvement for the Tropics. Centro Internacional de Agricultura Tropical (CIAT), Cali, Colombia.

Cilliers AJ, Herselman L, Pretorius ZA, 2000. Genetic variability within and among mycelial compatibility groups of Sclerotium rolfsii in South Africa. Phytopathology 90: 1026-1031.

FAO, 2004. FAOSTAT database. http://faostat.fao.org.

Harman GE, 2001. Pythium spp. Compendium of pea diseases. Kraft JM, Pfleger FL,Ed). St. Paul Mn, USA: American Phytopathological Society.

Harvey P, 2004. Crop rotation would reduce Pythium root rot. Cropping Disease Management. http:/l www.clw.csiro.au/publications/farming ahead/2 004/_154.pdf

Kucharek T, 2000. Diseases of Agronomic and vegetable crops caused by Pythium. Plant Pathology Fact Sheet.

Levesque CA, De Cock AWAM. 2004. Molecular phylogeny and taxonomy of the genus Pythium. Mycologia Research 108:1363-1383.

Mahuku G, 2004. A simple extraction method suitable for PCR-based analysis of plant, fungal and bacterial DNA. Plant Molecular Biology 22:7181.

Malvic, D, Babadoost M, 2002. Root rot of peas. Report on Plant Diseases.http://ipm.edu/diseases/ series 900/rpd911/index.html.

Mukalazi, J. 2004. Pathogen variation and quantification of Pythium spp. in bean fields in Uganda. PhD thesis. Makerere University, Kampala, Uganda. $146 \mathrm{pp}$.

Nderitu JH, Buruchara RA, Ampofo JKO, 1997. Relationships between bean stem maggot, bean root rots and soil fertility. Literature review with emphasis on research in eastern and central Africa. African Highlands Initiative (AHI), Nairobi, KE. (Technical report series no.4). $16 \mathrm{pp}$.

Ocitti p'Obwoya CN, 1996. Agronomic studies of sweet potato intercropped with bean. PhD. Thesis. Makerere University.

Rusuku G, Buruchara RA, Gatabazi M, Pastor-Corrales MA, 1997. Effect of crop rotation on Pythium ultimum and other Pythium species in the soil. Phytopathology 52:27.

Sarikamis, G F, Yasar M, Bakir K, Kazan A. Ergul, 2009. Genetic characterization of green bean (Phaseolus vulgaris) genotypes from eastern Turkey. Genetics and Molecular Research 8(3): 880-887.

Thompson JD, Higgins DG, Gibson TJ, 1994. Clustal W: improving the sensitivity of progressive multiple sequence alignment through sequence weighting, position-specific gap penalties and weight matrix choice. Nucleic Acids Research 22: 4673-4680.

White JG, 1988. Studies on the biology and control of cavity spot of carrots. Annals of Applied Biology 113: 259-268.

White TJ, Bruns T, Lee S, Taylor J, 1990. Amplification and direct sequencing of fungal ribosomal RNA genes for phylogenetics. PCR Protocols, A Guide to Methods and Application. Innis, M. A., Gelfand, D. H., Sninksy, J. J., and White, T. J. (EdsAcademic Press, San Diego). pp. 315-322. 